\title{
KARAKTERISTIK EDIBLE FILM BERBASIS KARAGENAN DAN STEARIN SAWIT SEBAGAI KEMASAN PANGAN
}

\section{THE CHARACTERISTIC OF EDIBLE FILM BASED ON CARRAGEENAN AND PALM STEARIN FOR FOOD PACKAGING}

\author{
Yuni Adiningsih, Fauziati, Ageng Priatni \\ Balai Riset dan Standardisasi Industri Samarinda \\ JI. MT. Haryono/ Banggeris No.1 Samarinda \\ Alamat Email : y_adiningsih@yahoo.co.id
}

\begin{abstract}
ABSTRAK
Pengemasan produk pangan menggunakan edible film merupakan salah satu teknik pengawetan pangan untuk meningkatkan daya tahan dan kualitas bahan pangan selama penyimpanan. Penelitian penggunaan karagenan untuk bahan pembuatan edible film telah banyak dilakukan namun perlu ditingkatkan daya elastisitasnya. Stearin adalah fraksi lemak yang merupakan komponen hidrofobik pada formulasi edible film yaitu untuk memperbaiki fleksibilitas dan dapat menimbulkan efek kilap yang tidak dimiliki oleh Karagenan sebagai hidrokoloid. Penelitian ini bertujuan untuk mengetahui karakteristik edible film dari karagenan dengan variabel penambahan stearin sawit sebanyak $0.2 \mathrm{~g}, 0.4$ $\mathrm{g}$ dan $0.6 \mathrm{~g}$. Hasil terbaik diaplikasikan untuk pengemasan dodol labu kuning sehingga diketahui daya tahan keawetan produk dodol terhadap cemaran mikroba. Penggunaan stearin yang optimum untuk pembuatan edible film yang diaplikasikan ke dodol sebanyak $0.4 \mathrm{~g}$ dengan komposisi karagenan $0,8 \mathrm{~g}$ dan gliserol 0,5\% (v/v) dengan hasil uji sifat fisik mekanik tensile strength sebesar $110,67 \mathrm{kgf} / \mathrm{cm}^{2}$ dan persen pemanjangan sebesar $25,03 \%$. Hasil uji mikrobiologi dodol labu kuning yang dikemas dengan edible film dari karagenan lebih baik daripada dodol labu kuning yang dikemas plastik sampai 21 hari.
\end{abstract}

Kata kunci : Edible film, stearin sawit, dodol labu kuning

\begin{abstract}
Packaging of food products using edible film is one of the food preservation techniques to improve the durability and quality of food during storage. Research on the use of carrageenan as material of edible film had been conducted, butresults showed thatimprovement regarding its elasticitywas still needed. Stearin is a fat fraction, which is a hydrophobic component in an edible film formulation to improve flexibility and create a luminous effect that is not owned by carrageenan as a hydrocolloid. This study aimed to determine the characteristics of edible film from carrageenan with stearin derivation of oil palm as much as $0.2 \mathrm{gr}, 0.4 \mathrm{gr}$ and $0.6 \mathrm{gr}$. The best result was applied to dodol to assess the durability of dodol product against microbial contamination. The optimum use of stearin for edible film was applied to dodol as much as $0.4 \mathrm{gram}$ with the $0.8 \mathrm{grof}$ carrageenan and $0.5 \% \mathrm{~g} / \mathrm{ycerol}(\mathrm{V} / \mathrm{V})$ with the result of physical mechanical test of tensile strength of $110.67 \mathrm{kgf} / \mathrm{cm} 2$ and elongationpercentage of $25.03 \%$. Microbiological test showed that edible film use was better than dodol given plastic packaging until 21 days.
\end{abstract}

Keywords : edible film, palmstearin, dodol 


\section{PENDAHULUAN}

$\mathrm{K}$

esadaran masyarakat terhadap bahan kemasan yang tidak dapat didegradasi dan sebagai salah satu faktor pencemaran lingkungan menyebabkan terus dikembangkannya teknologi kemasan yang biodegradable. Edible film merupakan lapisan tipis yang menyatu dengan bahan pangan, layak dimakan dan dapat diurai oleh mikroorganisme.

Edible film merupakan jenis kemasan primer yang sangat prospektif dan aman, karena bersifat edible, alami, non toksik dan sangat praktis. Edible film merupakan lapisan tipis terbuat dari bahan-bahan yang dapat dimakan dengan melapisi komponen makanan atau diletakkan diantara komponen makanan yang berfungsi sebagai penahan (barrier) yang baik untuk perpindahan massa (kelembaban, lipid, cahaya, zat terlarut, gas $\mathrm{O}_{2}$ dan $\mathrm{CO}_{2}$ ), atau sebagai carrier bahan makanan atau bahan tambahan, dan dapat mencegah hilangnya senyawasenyawa volatile pada aroma atau flavour khas suatu produk pangan (Skurtys O et al., 2001).

Edible film atau coating dapat berasal dari bahan baku yang mudah diperbaharui seperti campuran lipid, polisakarida, dan protein, yang berfungsi sebagai barrier uap air, gas, dan zatzat terlarut lain serta berfungsi sebagai carrier (pembawa) berbagai macam ingredient seperti emulsifier, antimikroba dan antioksidan, sehingga berpotensi untuk meningkatkan mutu dan memperpanjang masa simpan buah-buahan serta sayuran segar (Lin dan Zhao, 2007). Beberapa aplikasi edible film berbasis hidrokoloid telah dilakukan. Menurut Warkoyo, dkk (2014), penambahan pati umbi kimpul ( $x$. sagittifolium) dengan penambahan kalium sorbat menyebabkan kuat tarik, ketebalan, laju transmisi uap air dan kehalusan permukaan edible film meningkat, tetapi kelarutannya dalam air menurun, sedangkan penambahan kalium sorbat dalam edible film menyebabkan persen pemanjangan dan laju transmisi uap air edible film meningkat, tetapi kuat tariknya menurun. Sementara edible film dengan perlakuan konsentrasi pati jagung 3\% dan perasan temu hitam $7 \%$ memiliki aktivitas antioksidan $52,10 \%$, total fenol $555,16 \mu \mathrm{g} / \mathrm{g}$, kadar air $12,57 \%$, transmisi uap air 0,50 g/m².jam, ketebalan

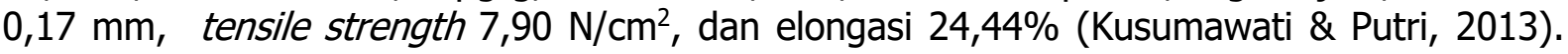
Listiyawati(2012), telah melakukan penelitian pembuatan edible film dari karagenan menggunakan plasticizerasam palmitat yang menyebutkan bahwa penggunaan asam palmitat yang semakin banyak menyebabkan turunnya nilai tensile strength dan modulus young, tetapi akan menaikkan nilai \% elongasi.

Penelitian edible film berbahan dasar lipid/lemak serta bahan tambahan yang bersifat hidrofobik seperti lemak dan asam lemak yang dapat meningkatkan sifat penghalang terhadap kelembaban dan mampu mempertahankan ketahanan terhadap uap, gas atau cairan, dan sifat sensoris produk yang diberi coating masih sangat jarang dilakukan.

Penggunaan stearin yang merupakan hasil samping dari pengolahan minyak sawit masih sangat terbatas dalam pemakaiannya sebagai coating. Palm Stearin (stearin sawit) merupakan fraksi minyak sawit yang mengandung asam lemak dan tersusun dari trigliserida jenuh. Stearin memiliki kadar $\mathrm{C}$ lebih dari 18 (sama halnya dengan lilin pada petrokimia) sehingga mempunyai sifat padat pada suhu ruang, dimana stearin memiliki titik leleh yang lebih rendah yaitu 44$56^{\circ} \mathrm{C}$ (Hariyadi, 2009). Penggunaan stearin di industri oleokimia diantaranya untuk pembuatan margarin, sabun, lilin dan bioplastik. Stearin yang merupakan fraksi lemak pada pembuatan edible film mempunyai fungsi sebagai komponen hidrofobik pada formulasi edible film yaitu untuk memperbaiki fleksibilitas dan dapat menimbulkan efek kilap yang tidak dimiliki oleh karagenan sebagai hidrokoloid.Edible film sebagai biopolimer yang terbuat dari hidrokoloid (protein, polisakarida, alginat), lemak (asam lemak, asigliserol, lilin) dan campuran beberapa bahan tersebut berfungsi melindungi produk dari kerusakan fisika, kimia dan mikrobiologi (Bourtoom, 2008). 
Penambahan lilin dan minyak dapat memberikan ketahanan kelembaban yang tinggi pada edible. Sifat hidrofobik dari senyawa lipid digunakan sebagai lapisan pelindung untuk mencegah pertukaran kelembaban antara produk makanan dan media sekitarnya atau antara komponen dalam makanan heterogen (Zahedi dkk., 2010).

Penelitian ini bertujuan untuk mengetahui karakteristik edible film dari karagenan dengan penambahan stearin sawit sebagai lemak untuk diaplikasikan dalam pengemasan dodol labu kuning dan dilakukan uji daya tahan keawetan produk terhadap cemaran mikrobiologi.

\section{METODOLOGI}

\section{Bahan dan Alat}

Bahan yang digunakan dalam penelitian ini terdiri dari palm stearin (lemak/lipid) yang diperoleh dari PT Sinar Mas, karagenan (sebagai hidrokoloid ), gliserol (sebagai plasticizer), dodol labu kuning, aquades dan media uji mikrobiologi. Peralatan terdiri dari timbangan analitik, oven, hot plate, magnetic stirrer, pengaduk, petridish, loyang kaca, thermometer, labu ukur, gelas ukur, erlenmeyer dan peralatan uji.

\section{Metode}

Penelitian dilakukan dalam skala laboratorium di Balai Riset dan Standardisasi Industri Samarinda dengan pengumpulan data menggunakan ulangan sebanyak 2 kali. Metode penelitian mengacu pada metode yang digunakan oleh Handito D.(2011)dengan dimodifikasi pada penggunaan bahan utama yaitu stearin sebagai lemak, karagenan sebagai hidrokoloid dan gliserol sebagai plasticizer. Adapun tahap kegiatan adalah sebagai berikut :

\section{Pembuatan Edible Film}

Dibuat larutan karagenan 0,8\% dengan cara menimbang tepung karagenan sebanyak 0,8 gram dilarutkan dalam $100 \mathrm{ml}$ aquades ke dalam beaker glass. Dilakukan pengadukan menggunakan magnetik stirer sampai homogen dan dipanaskan dengan menggunakan hot plate. Setelah tercapai suhu $60^{\circ} \mathrm{C}$ kemudian ditambahkan gliserol sebanyak $0,5 \%(\mathrm{v} / \mathrm{v})$ sebagai plasticizer dan stearin dalam bentuk lemak yang telah dicairkan lebih dahulu masingmasing sebanyak $0,2 \mathrm{~g}\left(\mathrm{~S}_{1}\right)$, 0,4 $\mathrm{g}\left(\mathrm{S}_{2}\right)$ dan $0,6 \mathrm{~g}\left(\mathrm{~S}_{3}\right)$ dalam campuran sambil diaduk terus dan dipanaskan sampai $80^{\circ} \mathrm{C}$ dan dipertahankan sampai 5 menit.

Selanjutnya larutan campuran yang terdiri dari karagenan, gliserol dan stearin masingmasing $S_{1}, S_{2}$ dan $S_{3}$ dituang dalam cetakan kaca dan dilakukan proses pengeringan dengan menggunakan oven pada suhu $50^{\circ} \mathrm{C}$ selama 12 jam, sehingga diperoleh lapisan/film tipis dan didinginkan pada suhu ruang.

\section{Metode Analisis}

Untuk mengetahui mutu edible film maka dilakukan pengujian sifat fisik dan mekanik meliputi kekuatan renggang putus (tensile strength) dan perpanjangan (elongation) yang diukur dengan alat Universal Testing Instrument. Dilakukan pula uji SEM (Scaning Electrone Microscope) untuk mengetahui pengaruh stearin pada lapisan film yang terbentuk. Edible film yang terbaik diaplikasikan ke dodol labu kuning.

\section{Aplikasi Edible Film pada Dodol Labu Kuning}

Dilakukan pembalutan produk dodol labu kuning menggunakan edible film serta pengamatan pada waktu 7 hari, 14 hari dan 21 hari. Selanjutnya dilakukan uji mikrobiologi terhadap kapang dan ALT sesuai metode uji SNI 01-2986-1992 (SNI dodol) pada tiap-tiap 
masa penyimpanan. Sebagai pembanding adalah produk dodol labu kuning yang telah dikemas dengan plastik.

\section{HASIL DAN PEMBAHASAN}

\section{Parameter Kekuatan Renggang Putus (tensile strength)}

Salah satu sifat mekanik edible film yang penting adalah tensile strength, karena terkait dengan kemampuan edible film untuk melindungi produk yang dilapisinya. Diperlukan nilai tensile strength yang tinggi sebagai kemasan produk pangan yang bertujuan untuk melindungi bahan pangan selama penanganan, transportasi dan pemasaran (Pitak dan Rakshit, 2011 dalam (Rusli et.al., 2017). Dilakukan pengujian sifat fisik mekanik edible film (uji tensile strength) untuk mengetahui penambahan stearin yang terbaik. Hasil pengujian sebagaimana gambar 1.

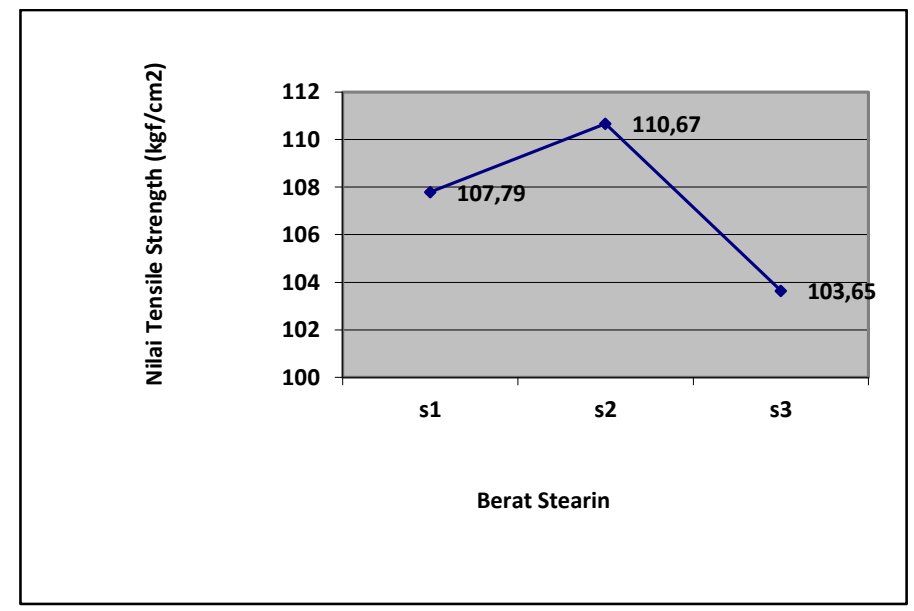

Gambar 1. Nilai tensile strength Edible Film Pada berbagai Berat Stearin

Gambar 1 menunjukan penggunaan stearin 0,4 gram memberi nilai yang optimum dengan nilai tensile strength sebesar $110,67 \mathrm{kgf} / \mathrm{cm}^{2}$ dibanding penggunaan stearin 0,2 gram yang menghasilkan nilai tensile strength sebesar $107,79 \mathrm{kgf} / \mathrm{cm}^{2}$. Nilai tersebut lebih tinggi dari yang ditetapkan JIS 1975 yaitu minimal sebesar $40 \mathrm{kgf} / \mathrm{cm}^{2}$ (Santoso et.al., 2013)

Tensile strength merupakan nilai hasil pengujian kekuatan (daya tahan) maksimum film setelah diberikan gaya tarik agar merenggang sampai putus (Handito D., 2011).Penggunaan stearin yang terlalu banyak cenderung menurunkan nilai tensile strength. Peningkatan penambahan stearin 0,6 gram mempunyai nilai yang lebih menurun yaitu $103,65 \mathrm{kgf} / \mathrm{cm}^{2}$. Menurut (Listiyawati, 2012) penggunaan asam lemak (lipid) semakin banyak menyebabkan tensile strength semakin rendah.Penambahan lipid semakin tinggi menurunkan kuat tarik hal ini disebabkan lipid tidak memiliki kelarutan yang baik terhadap air pada saat pembuatan larutan edible film. Sifat lipid non polar tidak dapat larut dengan baik pada pelarut air yang bersifat polar sehingga ikatan yang terjadi tidak terbentuk dengan baik dan dapat menurunkan kuat tarik. Hawa, et.al. (2013), menyebutkan bahwa nilai daya putus mengalami penurunan dengan meningkatnya konsentrasi lipid yang digunakan. Jenis lipid berpengaruh sangat nyata terhadap nilai daya putus edible film. Hal tersebut diduga karena perbedaan sifat mekanik dari bahan lipid yang digunakan. 


\section{Uji Pemanjangan atau elongation}

Persen pemanjangan (elongation) adalah persen pertambahan panjang maksimum pada saat terjadi peregangan hingga edible film terputus. Penggunaan stearin menunjukan hasil uji perpanjangan sebagaimana gambar 2 :

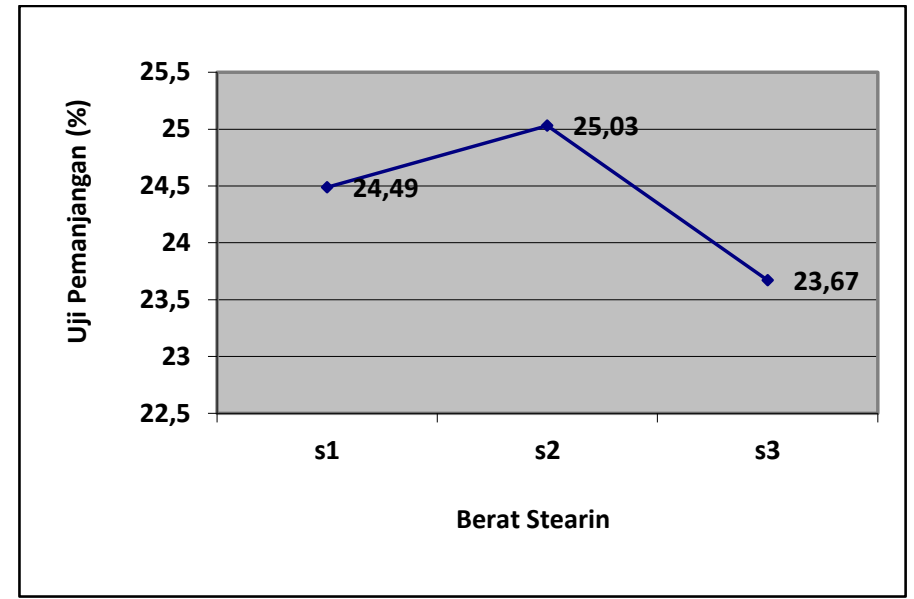

Gambar 2. Nilai Pemanjangan (Elongation) Edible Film Pada Berbagai Berat Stearin Sawit

Pada Gambar 2, persen pemanjangan edible film menggunakan stearin 0,4 gram dihasilkan nilai optimum sebesar 25,03\%. Penggunaan stearin 0,2 gram menghasilkan persen pemanjangan sebesar 24,49\% lebih tinggi dari penggunaan stearin 0,6 gram yaitu sebesar 23,67\%. Menurut(Listiyawati, 2012), semakin tinggi konsentrasi lipid maka nilai persen pemanjangannya semakin rendah. Menurut Kester dan Fennema (1994) dalam (Listiyawati, 2012), lipid diduga menghambat distribusi dan interaksi dengan molekul karagenan, sehingga meningkatkan struktur kohesif dan menurunkan fleksibilitas film. Elongation menunjukkan perubahan panjang maksimun saat memperoleh gaya tarik sampai film putus dibandingkan dengan panjang awalnya, elongation atau persentase pemanjangan suatu film dikatakan baik jika nilainya lebih dari $50 \%$ dan dikatakan buruk jika nilainya kurang dari $10 \%$ (Krochta dan De Mulder-Johnson, 1997 dalam Diova, dkk, 2013).

\section{Analisis morfologi permukaan dengan SEM (Scaning Electrone Microscope)}

Hasil uji fisik mekanik yang terbaik yaitu penggunaan stearin 0,4 gram dilakukan analisis morfologi permukaan (SEM) untuk mengetahui keterikatan molekul stearin (lipid) dalam karagenan. Hasil uji SEM yang dilakukan untuk edible film menggunakan stearin 0,4 gram dibandingkan dengan hasil uji SEM edible film tanpa stearin sebagaimana gambar 3a dan $3 \mathrm{~b}$.

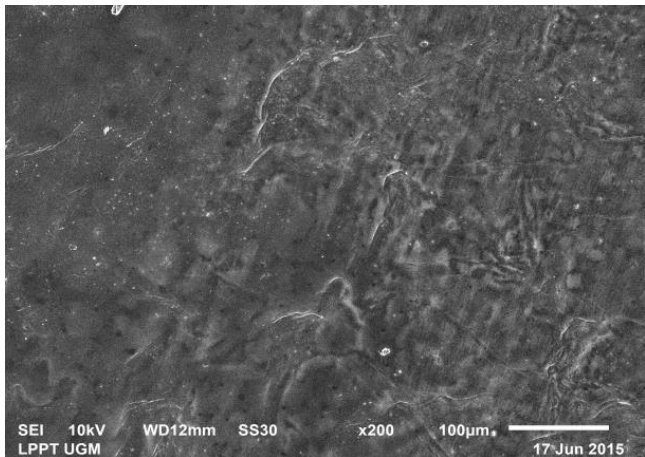

(a)

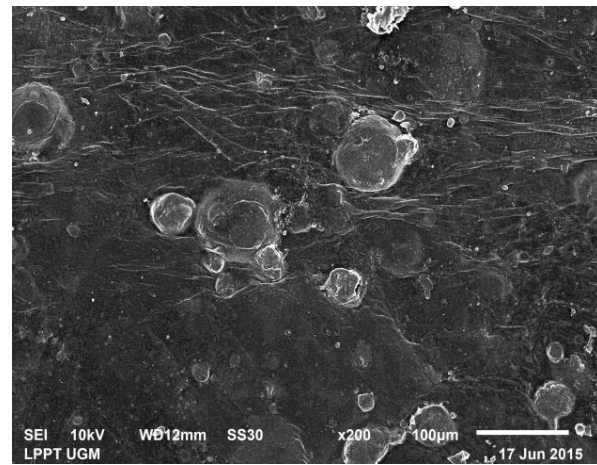

(b)

Gambar 3. Uji SEM Edible Film Tanpa dan Menambahkan Stearin Sawit 
Hasil uji SEM menunjukkan bahwa edible film tanpa stearin (Gambar 3a) menghasilkan permukaan edible coating yang lebih homogen dibandingkan dengan adanya penambahan stearin (Gambar 3b). Ini disebabkan karena stearin mengandung senyawa asam lemak jenuh yang tidak dapat bercampur sempurna karena mempunyai sifat hidrofobik. Asam lemak berupa lipid tidak memiliki kelarutan yang baik dengan air sehingga ikatan yang terbentuk antara gugus non polar dari lemak dan gugus polar dari air cenderung tidak stabil (Listiyawati, 2012). Penelitian Santoso (2017), menunjukan bahwa edible film yang terbuat dari pati ganyong dan lilin lebah terdapat bintik-bintik lilin lebah yang tidak terikat secara sempurna. Lilin lebah merupakan komponen yang bersifat non polar atau hidropobik, berbentuk padat dan sangat mudah mengkristal pada suhu ruang. Hal tersebut menyebabkan ikatan komplek dalam matrik edible film tidak terjadi secara sempurna dengan molekul lain yang mengakibatkan distribusi lilin lebah tidak merata. Lilin lebah merupakan jenis asam lemak jenuh sehingga untuk membentuk ikatan dengan senyawa lain lebih sulit dibanding dengan asam lemak tidak jenuh.

\section{Pengujian Cemaran mikrobiologi dodol yang dikemas Edible Film}

Edible film yang dibuat dari karagenan dan stearin dengan komposisi terbaik diaplikasikan ke dodol dan dilakukan uji mikrobiologi untuk parameter Angka Lempeng Total dan Kapang (sesuai SNI 01-2986-1992). Perlakuan tersebut dibandingkan dengan dodol yang diberi pelapis plastik.

\section{Angka Lempeng Total (ALT)}

Badan Pengawasan Obat dan Makanan (BPOM) dan Standar Nasional Nasional (SNI) mempersyaratkan kriteria mikrobiologi untuk sebagian besar bahan dan produk pangan. Pengujian mikrobiologi pangan bervariasi tergantung dari jenis pangannya. Untuk produk pangan pengujian yang sering dilakukan yaitu parameter nilai total mikroba atau angka lempeng total, total kapang dan bakteri koliform (Atma, 2016).

Dari hasil pengujian ALT pada dodol labu kuning diperoleh hasil sebagaimana Tabel 1.

Tabel 1. Angka Lempeng Total (ALT) Pada Masa Penyimpanan Dodol Labu Kuning

\begin{tabular}{|c|c|c|c|c|}
\hline \multirow{2}{*}{ KODE SAMPEL } & \multicolumn{4}{|c|}{ ANGKA LEMPENG TOTAL (koloni/g) } \\
\hline & 0 hari & 7 hari & 14 hari & 21 hari \\
\hline $\mathrm{A} 0$ & 0 & 0 & 0 & 0 \\
\hline $\mathrm{A} 1$ & 0 & 0 & $4 \times 10^{2}$ & $572 \times 10^{2}$ \\
\hline $\mathrm{A} 2$ & 0 & 0 & 0 & $78 \times 10^{1}$ \\
\hline
\end{tabular}

Pengujian Angka Lempeng Total (ALT) untuk dodol yang dikemas dengan plastik (A1) pada hari ke 14 sebagaimana Tabel 1 menunjukan telah tercemar mikroba yaitu sebesar $4 \times 10^{2}$ koloni/g dan meningkat pada hari ke-21 yaitu sebesar $572 \times 10^{2}$ koloni/g. Sementara dodol yang dikemas denganedible film (A2) tercemar mikroba setelah hari ke 21 yaitu sebesar $78 \times 10^{1}$ koloni/g. Menurut (Lin \& Zhao, 2007), edible film berfungsi sebagai carrier (pembawa) berbagai macam bahan seperti emulsifier, antimikroba dan antioksidan sehingga dapat memperpanjang masa simpan. Disamping itu edible film dari lipid lebih tahan terhadap kelembaban dibanding dari non lipid. 


\section{Kapang}

Pengujian cemaran mikroba berupa kapang dilakukan untuk mengetahui pengaruh edible film terhadap jumlah kapang pada dodol labu kuning. Dari uji Kapang diperoleh hasil sebagaimana Tabel 2.

Tabel 2. Jumlah Kapang Pada Masa Penyimpanan Dodol Labu Kuning

\begin{tabular}{ccccc}
\hline KODE SAMPEL & \multicolumn{4}{c}{ KAPANG } \\
& 0 hari & 7 hari & 14 hari & 21 hari \\
A0 & negatif & negatif & negatif & negatif \\
A1 & negatif & negatif & positif & positif \\
A2 & negatif & negatif & negatif & positif \\
\hline
\end{tabular}

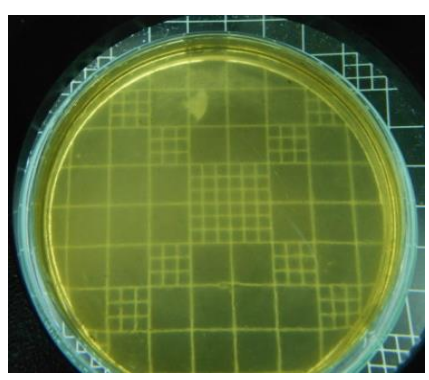

a). Blangko

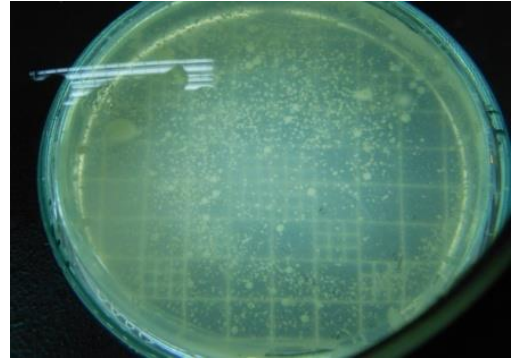

(b). Kemasan Plastik

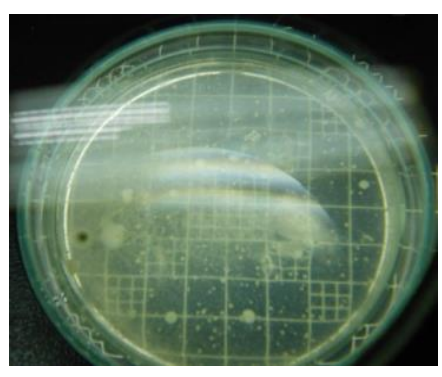

(c). Kemasan Edible Film

Gambar 4. Hasil Uji Kapang Pada Hari Penyimpanan ke-21

Pengujian kapang terlihat pada penyimpanan hari ke-14 pada dodol yang dikemas menggunakan plastik (A1) sementara dodol yang dikemas menggunakan edible film (A2) terlihat positif pada penyimpanan hari ke 21 . Dari hasil uji yang diperoleh menunjukkan bahwa kemasan edible film mampu melindungi dodol dari tumbuhnya kapang sampai 21 hari dibandingkan dengan kemasan plastik. Standar mutu makanan dodol untuk parameter uji kapang tidak boleh tercemar kapang atau tidak boleh ada (SNI 01-2986-1992). Selain itu edible film mempunyai kelebihan yaitu berupa kemasan yang dapat dimakan.

Kapang akan berkembang biak bila tempat tumbuhnya cocok untuk pertumbuhan. Di samping itu kapang tertentu ada yang menghasilkan zat racun (toksin) seperti jamur Aspergilus flavus yang dapat menghasilkan aflatoksin. Tercemarnya dodol oleh kapang dapat disebabkan karena kurang higienisnya proses pembuatan dodol sehingga terjadi kontaminasi silang atau tercemarnya mikroorganisme luar baik melalui kontak langsung dari tangan atau dari udara (Atma, 2016).

\section{KESIMPULAN}

Penggunaan stearin yang terbaik untuk pembuatan edible film yang diaplikasikan ke dodol sebanyak $0,4 \mathrm{~g}$ dengan komposisi karagenan $0,8 \mathrm{~g}$ dan gliserol 0,5\% (v/v) dengan hasil uji sifat fisik mekanik tensile strength sebesar $110,67 \mathrm{~kg} / \mathrm{cm}^{2}$ dan persen pemanjangan sebesar $25,03 \%$. Hasil uji mikrobiologi penggunaan edible film lebih baik daripada dodol yang diberi kemasan plastik sampai 21 hari. 


\section{UCAPAN TERIMA KASIH}

Terima kasih pada Balai Riset dan Standardisasi Industri Samarinda yang telah memberikan dana penelitian melalui DIPA Tahun 2015 sehingga dapat digunakan sebagai bahan tulisan sehingga artikel ini dapat diselesaikan.

\section{DAFTAR PUSTAKA}

Atma, Y. (2016). Angka Lempeng Total ( ALT ), Angka Paling Mungkin ( APM ) Dan Total Kapang Khamir Sebagai Metode Analisis Sederhana Untuk Menetukan Standar Mirobiologi Pangan Olahan Posdaya. Jurnal Teknologi Universitas Muhammadiyah Jakarta, $8(2)$.

Bourtoom, T. (2008). Review Article Edible films and coatings: Characteristics and Properties. International Food Research Journal, 15(3), 237-248.

Diova D., YS. Darmanto, L. R. (2013). Karakterisasi Edible Film Komposit Semirefined Karaginan dari rumput Laut Eucheuma Cottonii dan Beeswax. Pengolahan Dan Bioteknologi Hasil Perikanan, 2, 1-10.

Handito D. (2011). Pengaruh Konsentrasi Karagenan terhadap Sifat Fisik dan Mekanik Edible Film. Agroteksos, 21(2-3), 151-157.

Hariyadi P. (2009). High Grade Specialty Fats, 41-43.

Hawa, L. T., Thohari, I., \& Radiati, L. E. (2013). Pengaruh Pemanfaatan Jenis dan Konsentrasi Lipid Terhadap Sifat Fisik Edible Film Komposit Whey-Porang. Jurnal IImu-I/mu Peternakan, 23(1), 35-43. Retrieved from http://www.jiip.ub.ac.id/index.php/jiip/article/view/144

Kusumawati, D. H., \& Putri, W. D. R. (2013). Karakteristik Fisik Dan Kimia Edible Film Pati Jagung Yang Diinkorporasi Dengan Perasan Temu Hitam. Jurnal Pangan Dan Agroindustri, 1(1), 90-100. Retrieved from http://jpa.ub.ac.id/index.php/jpa/article/view/9

Lin, D., \& Zhao, Y. (2007). Innovations in the Development and Application of Edible Coating for Fresh and Minimally Processed Fruits and Vegetables. Comprehensive Reviews in Food Science and Food Safety, 6(3), 60-75. https://doi.org/10.1111/j.15414337.2007.00018.x

Listiyawati, O. (2012). Pengaruh Penambahan Plasticizer Palmitat Terhadap Karakter Edible Film Karaginan. Universitas Sebelas Maret, Solo.

Rusli A., Metusalach, Salengke, T. M. (2017). Karakterisasi Edible Film Karagenan Dengan pemlastis gleserol. Jurnal Pengolahan Hasil Perikanan: iIPB, 20, 219-229.

Santoso, B., -, H., Ariani, V., \& Pambayun, R. (2013). Charateristics of Edible Film from Field Eel Surimi and Tapioca Starch. Jurnal Teknologi Dan Industri Pangan, 24(1), 48-53. https://doi.org/10.6066/jtip.2013.24.1.48

Santoso B, Hilda Z, Priyanto G, P. R. (2017). Perbaikan Sifat Laju Transmisi Uap Air dan Antibakteri Edible Film dengan Menggunakan Minyak Sawit dan Jeruk Kunci. Agritech Universitas Sriwijaya Palembang, 373), 263-270.

Skurtys O, Acevedo C, Pedreschi F, Enrione J, Osorio F, \& Aguilera J. (2001). Food Hydrocolloid Edible Films and Coatings. Science \& Engineering, 34.

Warkoyo, Rahardjo, B., Marseno, D. W., \& Karyadi, J. N. W. (2014). Sifat Fisik, Mekanik dan Barrier Edible Film Berbasis Pati Umni Kimpul (Xanthosoma sagittifolium) yang Diinkorporasi dengan Kalium Sorbat. Agritech, 34(1), 72-81.

Zahedi, Y., Ghanbarzadeh, B., \& Sedaghat, N. (2010). Physical properties of edible emulsified films based on pistachio globulin protein and fatty acids. Journal of Food Engineering, 100(1), 102-108. https://doi.org/10.1016/j.jfoodeng.2010.03.033 